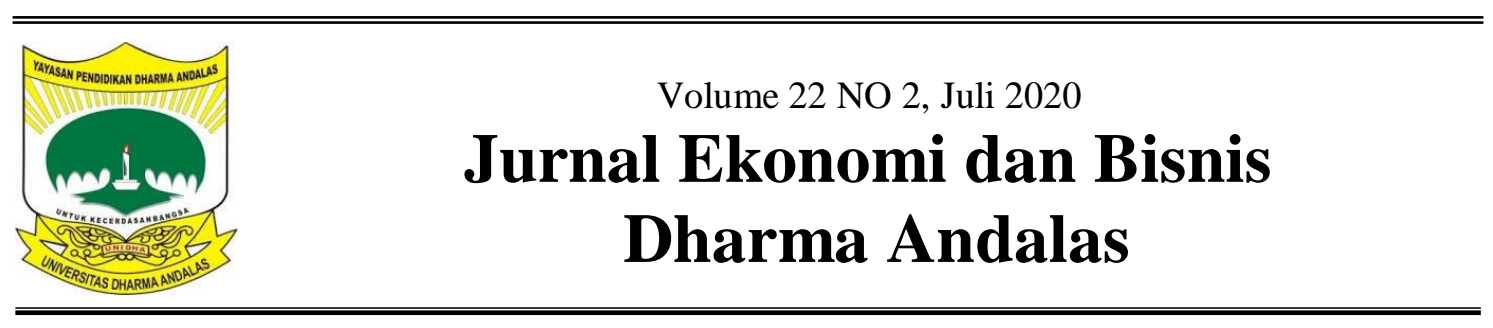

\title{
Disparitas Pendapatan dan Pengembangan Ekonomi Lokal di Kota Surabaya
}

\author{
Nurullaili Mauliddah \\ Universitas Muhammadiyah Surabaya \\ nurullaili-mauliddah@fe.um-surabaya.ac.id
}

\begin{abstract}
The purpose of this study is to explain and find out whether local economic development in the city of Surabaya has been going well and have an impact on decreasing disparity between subdistricts in Surabaya. The research method used is quantitative descriptive with SWOT analysis and Williamson Index $(I W)$. The instrument used in obtaining primary data was a questionnaire distributed to MSMEs under the guidance of the Surabaya City Government by sampling using Proportional Stratified Random Sampling. The results of the study illustrate the potential for the local economy to have been developed and facilitated by the government in the form of training, access to capital, facilitation of business legality, etc. However, the disparity between subdistricts is still relatively high with the calculation of the average Williamson Index of 0.5 in the period 2014-2018. Therefore, government intervention is still very much needed in developing the local economic potential of Surabaya City
\end{abstract}

Keywords: local economy, income disparity, SWOT analysis

\begin{abstract}
ABSTRAK
Tujuan dari penelitian ini untuk menjelaskan dan mengetahui apakah pengembangan ekonomi lokal di Kota Surabaya telah berjalan dengan baik dan memberikan dampak terhadap penurunan disparitas antar wilayah kecamatan di Kota Surabaya. metode penelitian yang digunakan adalah deskriptif kuantitatif dengan alat analisis SWOT dan perhitungan Indeks Williamson (IW). Instrumen yang digunakan dalam menggali data primer adalah kuesioner yang disebar kepada pelaku UMKM binaan Pemerintah Kota Surabaya dengan pengambilan sampel menggunakan tehnik Proportional Stratified Random Sampling. Hasil penelitian menunjukkan potensi ekonomi lokal telah dikembangkan dan difaslitasi oleh pemerintah baik dalam bentuk pelatihan, akses modal, fasilitasi legalitas usaha dsb. Namun demikian, disparitas antar wilayah kecamatan masih tergolong tinggi dengan hasil perhitungan Indeks Williamson rata-rata dalam kurun waktu tahun 2014-2018 sebesar 0,5. Oleh karena itu, intervensi pemerintah masih sangat dibutuhkan dalam pengembangan potensi ekonomi lokal Kota Surabaya.
\end{abstract}

Kata Kunci : ekonomi lokal, disparitas pendapatan, analisis SWOT

\section{PENDAHULUAN}

Paradigma baru kebijakan ekonomi yang lebih berbasis pada kemampuan ekonomi lokal dengan mengenali potensi, karakter ekonomi, sosial dan fisik tiap-tiap wilayah, termasuk interaksinya dengan wilayah kecamatan lain (Khairunnisa \& Hidayat,
2015). Sinergisitas kemampuan ekonomi lokal ini diharapkan dapat memperkuat daya saing ekonomi (Nugroho, 2018). Terwujudnya ekonomi lokal yang mampu meningkatkan kesejahteraan masyarakat tidak pernah lepas dari peranan pemerintah dalam mengkoordinasikan (Confrence, 2009), 
memfasilitasi, membangun semangat enterpreneur masyarakat (Mulyana et al., 2017), serta memberikan stimulasi kepada masyarakat agar bergerak untuk menggeliatkan ekonomi (Dewandaru \& Purnamaningsih, 2017). Ditinjau dari aspek peran dan pelayanan pemerintah dibidang ekonomi, selama ini investasi yang masuk dan berkembang di Kota Surabaya kurang mendorong tumbuhnya investasi lokal (Asriningputri \& Handayeni, 2019), dimana produkproduk unggulan daerah masih mengalami hambatan dibidang pemasaran, permodalan, pemanfaatan teknologi dan informasi, sehingga kerjasama ekonomi antar wilayah maupun antar pelaku ekonomi lokal belum menunjukkan sinergisitas, akibatnya banyak produk-produk unggulan Kota Surabaya yang belum dikenal.

Potensi wilayah Kota Surabaya masih banyak yang perlu dikembangkan dalam rangka mendukung kemandirian ekonomi lokal masyarakat. lokasi Kota Surabaya berada di pesisir pantai utara pulau Jawa memberikan peluang besar dalam bidang perikanan dan kelautan. Masyarakat pesisir Kota Surabaya telah memanfaatkan peluang tersebut yang tercermin dari sebagian besar profesi sebagai nelayan dan perdagangan hasil laut. Produk-produk masyarakat ini memang belum mampu menjadi komoditi yang memberikan kontribusi terbesar dalam perekonomian Kota Surabaya. Namun demikian, jika pengelolaan dan pedampingan yang dilakukan pemerintah dilaksanakan secara berkesinambungan maka akan mampu mengangkat potensi besar tersebut.

Intervensi pemerintah dalam membangun ekonomi lokal Kota Surabaya diharapkan dapat terwujud melalui berbagai bentuk kinerja. Sebagai koordinator dalam mengatur pengembangan potensi ekonomi masyarakat, pemerintah berkewajiban memberikan peluang kepada masyarakat untuk bersosialisasi dan berkerjasama dengan wilayah lain dengan tujuan meningkatkan pendapatan dan kesejahteraanya (Kaplanova, 2016). Sebagai fasilitator, pemerintah menyediakan bantuan kepada masyarakat baik dalam bentuk permodalan baik melalui dana APBD maupun dengan menghubungkan pelaku usaha masyarakat dengan otoritas pengelola keuangan seperti perusahaanperusahaan besar yang memberikan bantuan dana dalam bentuk pinjaman untuk pengusaha-pengusaha dengan tujuan membantu meningkatkan dan mengembangkan ekonomi lokal khususnya usaha yang dilakukan oleh masyarakat (Indratno \& Agustina, 2005). Selain itu, pemerintah berperan dalam mewujudkan jiwa dan ruh enterpreneurship pada masyarakat (Lestari \& Gunawan, 2017). Dengan demikian masyarakat tidak menggatungkan diri dengan bekerja kepada orang lain namun mampu membangun usaha sendiri dan mengelola secara pribadi (Syariful, 2018). Hal ini akan mampu meningkatkan kemandirian ekonomi masyarakat lokal (Husna, 2013).

Secara makro, kota Surabaya memiliki kemampuan ekonomi yang besar dibandingkan kota-kota lainnya di Jawa timur. Dari angka PDRB ADHB dan ADHK Kota Surabaya selalu mengalami peningkatan setiap tahunnya. Pada tahun 2018 PDRB Kota Surabaya mampu mencapai angka Rp 544.594.457,78 Juta untuk PDRB ADHB dan pada PDRB ADHK telah mencapai Rp387.292.704,10 dengan Sektor penyumbang PDRB tertinggi yaitu sektor perdagangan besar dan eceran, reparasi mobil dan sepeda motor (Surabaya, 2018). 
Secara administratif, Kota Surabaya terbagi atas 31 Kecamatan dengan jumlah kelurahan sebanyak 154 kelurahan. Masing-masing kelurahan terpecah menjadi RT dan RW, untuk RT dan RW di Kota Surabaya terdapat 1.360 RW dan 9.101 RT. Jumlah penduduk Kota Surabaya tahun 2019 berdasarkan data SIAK sebesar 3.159.481 Jiwa. Peran-peran pemerintah Kota Surabaya dalam rangka meningkatkan geliat ekonomi lokal tidak lain bertujuan untuk menurunkan ketidakmerataan pendapatan masyarakat masing-masing kecamatan (Xue, 2012). Angka disparitas antar wilayah di kota Surabaya tergolong tinggi (Nuraini, 2017). Hal ini tercermin dari tingginya PDRB Kecamatan di satu wilayah namun di beberapa wilayah masih memiliki angka PDRB Kecamatan yang rendah. Kondisi yang demikian menuntut pemerintah untuk mengambil tindakan agar angka kemerataan semakin meningkat dan disparitas semakin menurun melalui investasi dan pemberdayaan masyarakat (Azka Fauzia \& Aji Suseno, 2018). Investasi Kota Surabaya dari tahun ke tahun selalu mengalami peningkatan demi tercapainya kemerataan. Tahun 2017 sebesar Rp. 48.650.395.938.982, Tahun 2018 Rp.51.319.023.276.746 dan untuk Tahun 2019 : Rp. 62.390.017.021.951.

Berdasarkan penjelasan tersebut dalam rangka mengatasi masalah disparitas antar wilayah kecamatan di Kota Surabaya, perlu adanya evaluasi atas pelaksanaan intervensi pemerintah agar dapat mengatasi masalah disparitas antar wilayah kecamatan dan meningkatkan kemerataan antar kecamatan.

\section{METODE PENELITIAN}

Penelitian ini menggunakan dua dasar desain penelitian yaitu exploratory dan descriptive research yang dilakukan secara bertahap. Data yang digunakan merupakan data primer yang diperoleh melalui penyebaran kuesioner serta data sekunder dari instansi terkait yaitu BPS Kota Surabaya, Bappeko Surabaya, Dinas Koperasi dan UMKM Kota Surabaya. Kuesioner disebarkan kepada responden pelaku UMKM dan konsumen UMKM sebanyak 70 responden dengan tehnik pengambilan sampel stratified random sampling. Metode yang digunakan menggunakan metode analisis SWOT (Strenght, Weakness, Opportunities, Threat). Menurut Pearce and Robinson (2003,134), analisa SWOT perlu dilakukan karena analisa SWOT untuk mencocokkan "fit" antara sumber daya internal dan situasi eksternal. Perhitungan Indeks Williamson (IW) digunakan untuk mengukur tingkat ketimpangan antar kecamatan (Khairunnisa \& Hidayat, 2015). Ketimpangan pembangunan ekonomi dapat dianalisis dengan rumusan sebagai berikut (Syafrizal, 1997):

$$
\text { IW }=\frac{\sqrt{\sum\left(\mathbf{Y}_{\mathbf{i}}-\mathbf{Y}\right)^{2}\left(\mathbf{f}_{\mathbf{i}} / \mathbf{n}\right)}}{\mathbf{Y}} \quad 0<\mathrm{IW}<1
$$

Keterangan:

IW : Indeks Williamson

Yi : PDRB per kapita di kecamatan i

Y : PDRB per kapita rata-rata Kota Surabaya

fi : Jumlah penduduk kecamatan i

n : Jumlah penduduk Kota Surabaya

\section{HASIL DAN PEMBAHASAN}

Kemeretaan selalu dikaitkan dengan pendapatan pada masing-masing wilayah. 31 kecamatan yang berada di Surabaya memiliki tingkat pendapatan yang berbeda. Ditinjau dari PDRB masing-masing kecamatan tersebut diketahui terdapat kecamatan dengan PDRB yang tinggi yaitu Kecamatan Gubeng namun terdapat pula kecamatan dengan PDRB terendah yaitu kecamatan Jambangan. 
Kecamatan dengan PDRB ADHK tertinggi adalah Kecamatan Gubeng dengan perolehan sebesar Rp 31.590,30 milyar di tahun 2018 dan selanjutnya disusul oleh Kecamata Genteng sebesar 28.505,39 milyar. Sedangkan untuk kecamatan dengan PDRB ADHK terendah adalah Kecamatan Jambangan sebesar Rp 3.485,24 milyar ditahun yang sama dan kecamatan Benowo sebesar Rp3.906,21 miliar. Dari data tersebut menunjukkan bahwa pendapatan yang tinggi terjadi pada kecamatan yang berada di wilayah tengah kota sedangkan wilayah pinggiran memperoleh pendapatan lebih rendah walaupun distribusi sektor yang memberikan kontribusi pendapatan terhadap PDRB yang mendominasi sama yaitu Sektor Perdagangan Besar dan Eceran, dan Reparasi Mobil dan Sepeda Motor namun jumlah total PDRB tersebut masih terdapat perbedaan yang cukyp signifikan. Hal ini dikarenakan adalah jumlah potensi ekonomi dan kecepatan perkembangan dan pertumbuhan ekonomi pada masingmasing wilayah tersebut berbeda.

Dari data inflasi sektoral kecamatan di Kota Surabaya dapat diketahui bahwa inflasi tertinggi pada tahun 2018 terjadi pada Kecamatan Sambikerep dan Kecamatan Simokerto yaitu 4,53 dan 4,50. Tingginya inflasi tersebut jika dibandingkan dengan kecamatan lainnya didominasi oleh sektor pengadaan listrik dan gas. Selanjutnya selain sektor tersebut yang berperan dalam menaikkan inflasi pada kecamatan tersebut adalah sektor Pertanian, Kehutanan, dan Perikanan untuk Kecamatan Simokerto sedangkan kecamatan Sambikerep disebabkan oleh inflasi pada sektor Administrasi Pemerintahan, Pertahanan dan Jaminan Sosial Wajib.

Dengan menggunakan formula perhitungan Indeks Williamson, tingkat ketimpangan Kota Surabaya berada masih dalam ambang batas aman yang berada di bawah angka 1 .

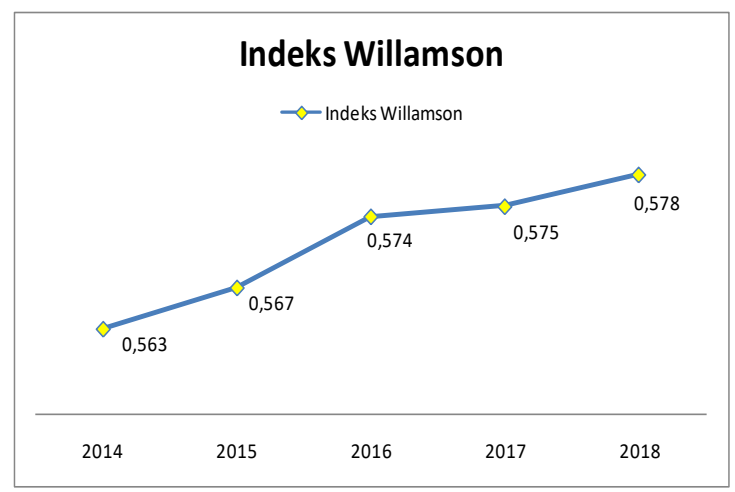

Gambar 1:

\section{Indeks Williamson Kota Surabaya}

Tahun 2014-2018

Pada Indeks Williamson, variabel yang digunakan adalah pendapatan perkapita dan jumlah penduduk dari kecamatan-kecamatan dan Kota Surabaya dari tahun 2014 hingga 2018. Berdasarkan Indeks Williamson pada gambar tersebut, rata-rata tingkat ketimpangan Kota Surabaya adalah diatas 0,5. Hal ini menunjukkan masih lebarnya perbedaan pendapatan dari satu wilayah dengan wilayah kecamatan lainnya. Dari hasil tersebut, Indeks Williamson selalu mengalami peningkatan secara terus menerus di Kota Surabaya. Hal ini menuntut Pemerintah untuk selalu aktif dalam menyusun strategi pembangunan agar disparitas di Kota Surabaya semakin menurun. Berikut beberapa strategi yang dapat dilaksanakan untuk mengatasi masalah disparitas wilayah di Kota Surabaya.

Intervensi pemerintah di Kota Surabaya sangat perlu diselenggarakan secara terperinci, optimal dan berkesinambungan melalui pengembangan iklim usaha yang kondusif, pemberiaan kesempatan berusaha, dukungan, perlindungan dan pengembangan usaha seluas-luasnya, sehingga mampu meningkatkan kedudukan, peran dan potensi ekonomi lokal masyarakat . 
Survey yang dilakukan di dalam kajian evaluasi ini adalah kepada pelaku UMKM yang memperoleh intervensi pemerintah baik dalam bentuk pelatihan, pendampingan, maupun fasilitasi oleh Pemerintah Kota Surabaya. UMKM pada tahun 2018 dan 2019 dengan pengambilan sampel secara random untuk menunjukkan informasi dan kondisi intervensi pemerintah yang telah dilaksanakan selema ini sehingga survey dilakukan kepada 80 UMKM yang mengikuti pembinaan dan fasilitasi serta pedagang kaki lima yang telah memperoleh bantuan untuk berjualan di Sentra PKL yang dibangun oleh Pemerintah Kota Surabaya tersebar diseluruh kecamatan.

Hasil analisis SWOT akan dijadikan landasan dalam penyusunan strategi kebijakan guna mencapai

\section{Tabel .1}

Analisis Kekuatan, Kelemahan, Peluang dan Ancaman Pengembangan Potensi Ekonomi Lokal Kota Surabaya

\begin{tabular}{|c|c|c|c|c|}
\hline & $\begin{array}{l}\text { Strenghts/ } \\
\text { Kekuatan }\end{array}$ & $\begin{array}{l}\text { Weakness / } \\
\text { Kelemahan }\end{array}$ & $\begin{array}{l}\text { Opportunities/ } \\
\text { Peluang }\end{array}$ & $\begin{array}{l}\text { Threats/ } \\
\text { Ancaman }\end{array}$ \\
\hline $\begin{array}{l}\text { Pengembangan } \\
\text { Potensi } \\
\text { ekonomi lokal }\end{array}$ & $\begin{array}{l}\text { Kota Surabaya } \\
\text { sebagai kota } \\
\text { metropolitan } \\
\text { - Pusat perekonomian } \\
\text { Indonesia Timur } \\
\text { - Banyak potensi } \\
\text { ekonomi lokal } \\
\text { - Kota dengan latar } \\
\text { belakang sejarah } \\
\text { yang kuat dan } \\
\text { diketahui banyak } \\
\text { masyarakat } \\
\text { - kenampakan alam } \\
\text { berada dipesisir } \\
\text { - masyarakat yang } \\
\text { heterogen }\end{array}$ & $\begin{array}{l}\text { - Jumlah penduduk } \\
\text { yang besar } \\
\text { - arus urbanisasi yang } \\
\text { berlangsung setiap } \\
\text { tahun } \\
\text { - masyarakat mudah } \\
\text { terpengaruh budaya } \\
\text { baru motivasi masyarakat } \\
\text { - mompu } \\
\text { untuk secara } \\
\text { berkembang lebih } \\
\text { mandiri untuk } \\
\text { berdaya }\end{array}$ & $\begin{array}{l}\text { - Tingkat kunjungan } \\
\text { yang tinggi } \\
\text { - Pendapatan } \\
\text { masyarakat semakin } \\
\text { meningkat } \\
\text { - Akses promosi yang } \\
\text { mudah } \\
\text { - masih terdapat } \\
\text { banyak potesi } \\
\text { ekonomi lokal yang } \\
\text { belum dikembangkan } \\
\text { - } \\
\text { multietnis masyarakat }\end{array}$ & $\begin{array}{l}\text { - } \text { produk luar } \\
\text { negeri semakin } \\
\text { mudah masuk } \\
\text { - teknologi yang } \\
\text { mempermudah } \\
\text { masyarakat } \\
\text { untuk } \\
\text { berbelanja } \\
\text { - persaingan usaha } \\
\text { yang semakin } \\
\text { ketat } \\
\text { - generasi muda } \\
\text { melupakan } \\
\text { warisan budaya } \\
\text { dan adat }\end{array}$ \\
\hline
\end{tabular}

Sumber : Hasil Penelitian, Data diolah, 2020.

Potensi dari bidang kuliner, fashion dan produk hasil alam masih bisa dikembangkan dan perhatian pemerintah akan hal tersebut menjadi kekuatan besar untuk meningkatkan ekonomi dan kesejahteraan masyarakat. pasar yang besar di Kota Surabaya menjadi kekauatan dengan skor 0,4. pengembangan potensi lokal yang tepat untuk dikembangkan. Pada tabel 1 disajikan unsur dan variabel sebagai penilaian kekuatan, kelemahan, peluang dan tantangan kondisi ekonomi lokal Kota Surabaya.

Berdasarkan matriks IFAS pada tabel 2, terlihat bahwa faktor lokasi dan kenampakan alam merupakan kekuatan terbesar bagi potensi ekonomi lokal Kota Surabaya, dengan skor sebesar 0,4. Diharapkan dengan intervensi pemerintah dapat meningkatkan pengembangan potensi lokal yang telah ada. Faktor kedua yang menjadi kekuatan Kota Surabaya adalah kota Surabaya sebagai pusat perekonomian untuk Indonesia bagian timur akan menjadi potensi besar pasar bagi pengembangan ekonomi lokal. 
kepedulian masyarakat dalam menjaga dan mengembangkan potensi ekonomi yang ada diwilayahnya, dengan skor sebesar 0,26.

Kelemahan terbesar dari pengembangan potensi ekonomi lokal dalam sisi internal adalah rentannya pengaruh budaya luar kepada masyarakat (dengan skor 0,28). Hal ini dikarenakan Kota Surabaya sebagai kota metropolitan sehingga budaya baru sangat mudah untuk masuk dan melunturkan budaya yang sudah ada terutama untuk generasi muda. Kelemahan terbesar kedua dalam sisi internal pengembangan potensi ekonomi lokal Kota Surabaya adalah motivasi masyarakat untuk mampu berkembang secara mandiri untuk lebih berdaya dengan skor 0,24. Banyak artikel menjelaskan bahwa motivasi berusaha masyarakat lokal surabaya kalah dibandingkan dengan masyarakat urbanisasi dari daerah lain. Hal ini menjadikan peluang untuk berkembang secara mandiri tergerus oleh masyarakat dari luar kota Surabaya. Hal ini berakibat pada ketergantungan masyarakat Kota Surabaya terhadap pemerintah dan usaha yang dikelola oleh masyarakat pelaku urbanisasi.

Tabel. 2

Tabel IFAS Potensi Ekonomi Lokal di Kota Surabaya

\begin{tabular}{|c|c|c|c|}
\hline Variabel & Bobot & Doting & Bobat y Doting \\
\hline \multicolumn{4}{|l|}{ Kekuatan } \\
\hline Kota Surabaya sebagai kota metropolitan & 0,1 & 4 & 0,4 \\
\hline Pusat perekonomian Indonesia Timur & 0,1 & 4 & 0,4 \\
\hline $\begin{array}{l}\text { Kota dengan latar belakang sejarah yang kuat dan } \\
\text { diketahui banyak masyarakat }\end{array}$ & 0,09 & 4 & 0,36 \\
\hline Banyak potensi ekonomi local & 0,09 & 3 & 0,27 \\
\hline kenampakan alam berada dipesisir & 0,1 & 4 & 0,4 \\
\hline masyarakat yang heterogen & 0,09 & 4 & 0,36 \\
\hline APBD Pemerintah Kota Surabaya yang besar & 0,1 & 3 & 0,3 \\
\hline \multicolumn{4}{|l|}{ Kelemahan } \\
\hline arus urbanisasi yang berlangsung setiap tahun & 0,07 & 4 & 0,28 \\
\hline Jumlah penduduk yang besar & 0,06 & 3 & 0,18 \\
\hline masyarakat mudah terpengaruh budaya baru & 0,07 & 3 & 0,21 \\
\hline $\begin{array}{l}\text { Rawan adanya inkonsistensi masyarakat karena } \\
\text { adanya urbanisasi }\end{array}$ & 0,06 & 3 & 0,18 \\
\hline $\begin{array}{l}\text { motivasi masyarakat untuk mampu berkembang } \\
\text { secara mandiri untuk lebih berdaya }\end{array}$ & 0,08 & 3 & 0,24 \\
\hline Tingkat partisipasi masyarakat yang kecil & 0,07 & 3 & 0,21 \\
\hline TOTAL & 1 & & 3,79 \\
\hline
\end{tabular}

Sumber : Hasil Penelitian, Data diolah, 2020.

Tabel 3:

Tabel EFAS Potensi Ekonomi Lokal di Kota Surabaya

\begin{tabular}{|c|c|c|c|}
\hline Variabel & \multirow{2}{*}{ Bobot } & \multirow{2}{*}{ Rating } & \multirow{2}{*}{ Bobot x Rating } \\
\hline Peluang & & & \\
\hline Tingkat kunjungan yang tinggi & 0,09 & 3 & 0,27 \\
\hline Pendapatan masyarakat semakin meningkat & 0,07 & 3 & 0,21 \\
\hline Akses promosi yang mudah & 0,1 & 4 & 0,4 \\
\hline
\end{tabular}




\begin{tabular}{|c|c|c|c|}
\hline Variabel & Bobot & Rating & Bobot x Rating \\
\hline $\begin{array}{l}\text { masih terdapat banyak potesi ekonomi lokal yang } \\
\text { belum dikembangkan }\end{array}$ & 0,09 & 3 & 0,27 \\
\hline Akses transportasi yang mudah & 0,11 & 4 & 0,44 \\
\hline $\begin{array}{l}\text { Kreatifitas masyarakat yang tinggi untuk } \\
\text { pengembangan }\end{array}$ & 0,08 & 3 & 0,24 \\
\hline \multicolumn{4}{|l|}{ Ancaman } \\
\hline generasi muda melupakan warisan budaya dan adat & 0,08 & 3 & 0,24 \\
\hline $\begin{array}{l}\text { teknologi yang mempermudah masyarakat untuk } \\
\text { berbelanja }\end{array}$ & 0,1 & 3 & 0,3 \\
\hline persaingan usaha yang semakin ketat & 0,06 & 3 & 0,18 \\
\hline produk luar negeri semakin mudah masuk & 0,1 & 4 & 0,4 \\
\hline Kondisi ekonomi yang tidak stabil & 0,1 & 3 & 0,3 \\
\hline Tidak mampu mempertahankan harga produk lokal & 0,1 & 4 & 0,4 \\
\hline TOTAL & 1 & & 3,65 \\
\hline
\end{tabular}

Sumber : Hasil Penelitian, Data diolah, 2020.

Pada faktor eksternal, peluang terbesar potensi ekonomi lokal di Kota Surabaya yang bisa dimanfaatkan untuk meningkatkan perekonomian dan pemenuhan kebutuhan masyarakat adalah infrastruktur yang mendukung dalam proses distribusi logistik, dengan skor sebesar 0,4. Hal ini menjadi sangat penting dikarenakan Kota Surabaya merupakan kota perdagangan dan jasa sehingga akses tersebut lebih mudah dijangkau. Faktor peluang terbesar kedua adalah akses promosi yang mudah menjadi pangsa pasar yang besar untuk potensi ekonomi lokal dengan skor 0,4. Dimana sebagai pusat perdagangan, Kota Surabaya merupakan pasar yang besar dengan didukung urbanisasi yang terus meningkat menjadikan ekonomi lokal yang masih dapat dikembangkan namun harus diimbangi dengan kreatifitas dan semangat masyarakat.

Faktor ancaman terbesar potensi ekonomi lokal di Kota Surabaya adalah produk luar negeri semakin mudah masuk, dengan skor sebesar 0,4. Tingginya kebutuhan akan bahan pokok, terkadang membuat pasokan bahan pokok berkurang dan akan terjadi peningkatan harga. Serta adanya globalisasi dan pasar bebas menyebabkan mudahnya barang dan jasa masuk serta keluar dari Kota Surabaya. Hal ini mengakibatkan ekonomi lokal memiliki pesaing yang pada dasarnya kualitas bahan pangan impor dari sisi penampakan lebih baik. Sehingga lebih mudah dalam menarik minat masyarakat untuk mengonsumsi hasil bahan impor dibandingkan dengan produk bahan pangan lokal. Potensi ekonom lokal yang sering terdapat bahan impor diantaranya produk fashion, makanan dll. Adapun faktor kedua yang merupakan ancaman eksternal pada potensi ekonomi lokal Kota Surabaya adalah Kondisi ekonomi yang tidak stabil dan teknologi yang mempermudah masyarakat untuk berbelanja, dengan skor masing-masing sebesar 0,3. Kondisi ekonomi yang tidak stabil menjadikan peluang pendapatan masyarakat dihadapkan pada berbagai pertimbangan untuk tidak memulai usaha baru, hal ini dikhawatirkan akan menurunkan pendapatan dan berdampak pada ruginya usaha yang dirintis. Selain itu teknologi yang semakin canggih ternyata tidak selamanya menjadi jalan pintas untuk menjual barang. Namun juga mampu menurunkan pendapatan dikarenakan semakin banyaknya pilihan masyarakat untuk membeli berbagai 
jenis produk, sehingga produk lokal yang tidak mengikuti pasar dunia maya tidak akan memperoleh konsumen.

Matriks IE (internal external) merupakan matriks portofolio yang memposisikan perusahaan dalam tampilan sembilan sel. Posisi suatu perusahaan dalam matriks IE ditentukan dari matriks EFAS dan matriks IFAS. Hasil skor total dari IFAS Matrix berada pada sumbu $X$ dan skor total dari EFAS Matrix berada pada sumbu Y. Dari hasil analisis, matriks IFAS kondisi potensi ekonomi lokal Kota Surabaya memiliki skor total 3,79 sementara matriks EFAS memiliki skor total 3,65. Pengaruh variabel dari dalam yang sangat besar pada Kota Surabaya menunjukkan kota
Surabaya berusaha mengembangkan potensi ekonomi lokal dan kesejahteraan bagi masyarakat, dimana pegembangan tersebut mampu menurunkan disparitas antar wilayah di kota Surabaya akan berdampak pada kesejahteraan masyarakat Kota Surabaya. Adapun matriks IE Kota Surabaya dideskripsikan pada tabel 4.

Menurut matriks IE, kondisi potensi ekonomi lokal Kota Surabaya pada berada pada kuadran I, di mana potensi ekonomi lokal Kota Surabaya memiliki situasi yang sangat menguntungkan, dengan memanfaatkan peluang menggunakan kelebihan yang dimiliki.

Tabel. 4

Kuadran Internal Eksternal Pengembangan Potensi Ekonomi Lokal

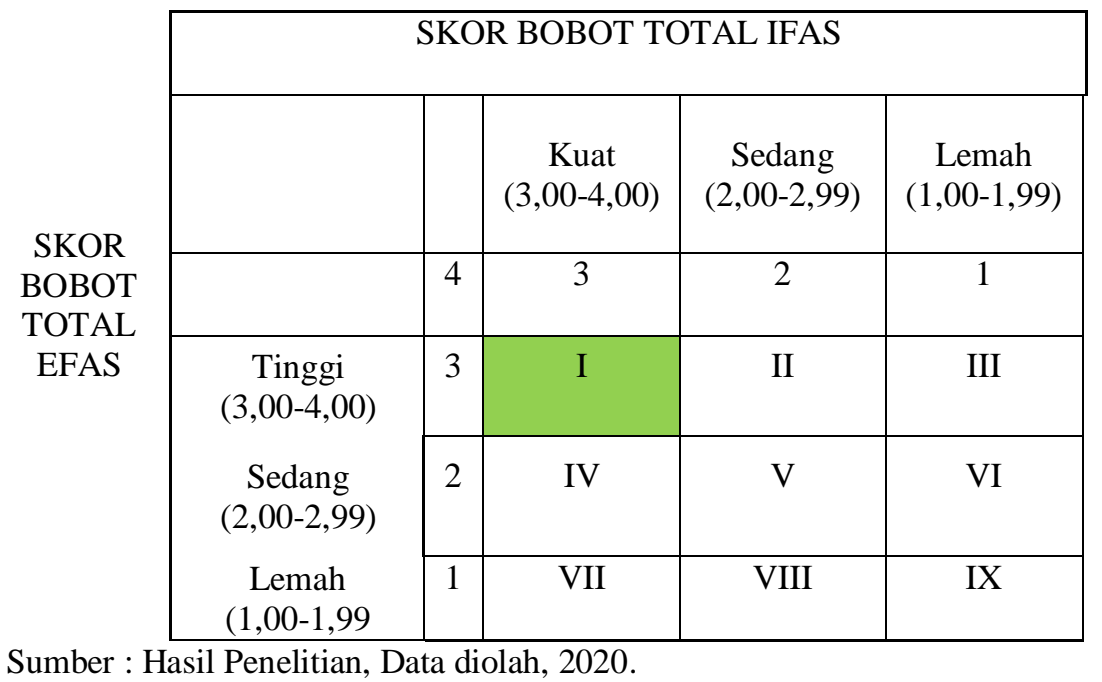

\section{SIMPULAN}

Dari hasil pembahasan yang telah dilakukan dapat diambil kesimpulan sebagai berikut:

1. Peran masing-masing Pemerintah terkait dalam menjalankan fungsinya untuk memberikan pelayanan kepada masyarakat telah berjalan dengan baik, dimana potensi ekonomi lokal telah dikembangkan dan difaslitasi oleh pemerintah baik dalam bentuk pelatihan, akses modal, fasilitasi legalitas usaha dsb.
2. Disparitas antar wilayah kecamatan masih tergolong tinggi dengan hasil perhitungan Indeks Williamson rata-rata dalam kurun waktu tahun 2014-2018 sebesar 0,5

3. Intervensi pemetintah masih sangat dibutuhkan oleh masyarakat untuk membantu dalam pengembangan potensi ekonomi local.

4. Intervensi pemerintah selama ini yang dilakukan oleh OPD selain menghasilkan dampak positif bagi masyarakat, juga memunculkan dampak 
positif bagi daya saing ekonomi lokal Kota Surabaya.

Agar tujuan pengembangan potensi ekonomi lokal dapat dapat menciptakan masyarakat yang berdaya saing, tangguh dan mandiri adalah melalui:

1. Menempatkan kesetaraan sebagai target kinerja para pelaksana pembangunan ekonomi. Hal ini dapat dilihat dari indikator-indikator apa saja yang digunakan untuk mengukur pemerataan.

2. Mengurangi kebijakan yang justru memperlebar ketimpangan.

3. Memberikan perhatian khusus pada sektor-sektor dominan, yang unggul, atau pun yang sedang bertumbuh di setiap kecamatan.

4. Pemerataan alokasi sumberdaya, capital, infrastruktur dan teknologi pada tiap kecamatan.

\section{DAFTAR PUSTAKA}

Asriningputri, N., \& Handayeni, K. D. M. E. (2019). Strategi Pengembangan Industri Pengolahan Hasil Perikanan Di Kecamatan Bulak Melalui Pendekatan Pengembangan Ekonomi Lokal (Pel). Jurnal Teknik Its, 7(2). Https://Doi.Org/10.12962/J2337353 9.V7i2.33116

Azka Fauzia, A., \& Aji Suseno, D. (2018). Analisis Determinan Disparitas Pendapatan Di Kawasan Purwomanggung Tahun 2009-2015. Economics Development Analysis Journal, 6(4), 436-444. Https://Doi.Org/10.15294/Edaj.V6i4. 22294

Confrence, 10th International. (2009). Finance And Economic Stability In The Context Of Financial Crisis.

Dewandaru, B., \& Purnamaningsih, N. (2017). Strategi Dalam Memajukan Industri Kreatif Dan Pengembangan Ekonomi Lokal Sebagai Daya Tarik Wisata (Studi Pada Kesenian Jaranan Di Kota Kediri). Ekonika: Jurnal Ekonomi Universitas Kadiri, 1(2). Https://Doi.Org/10.30737/Ekonika.V $1 \mathrm{i} 2.4$
Husna, N. (2013). Analisis Pengembangan Potensi Ekonomi Lokal Untuk Menguatkan Daya Saing Daerah Di Kabupaten Gresik. Jurnal Administrasi Publik Mahasiswa Universitas Brawijaya, 1(1), 72874.

Indratno, I., \& Agustina, I. H. (2005). Studi Kemampuan Masyarakat Dalam Pengembangan Ekonomi Lokal Sebagai Upaya Pengentasan Kemiskinan (Studi Kasus Desa Tegalurung Kecamatan Legonkulon Kabupaten Subang). Mimbar, Jurnal Sosial Dan Pembangunan, 21(3), 415-528.

Https://Doi.Org/10.29313/Mimbar.V 21i3.185

Kaplanova, P. (2016). Public Goods As Factors Of A Local Economic Development In Slovakia. Administratie $\mathrm{Si}$ Management Public, 2016(26), 6-24.

Khairunnisa, A., \& Hidayat, P. (2015). Analisis Disparitas Pembangunan Ekonomi Antar Kecamatan Di Kota Medan. Jurnal Ekonomi Dan Keuangan, 3(6), 14845.

Lestari, S., \& Gunawan, R. S. (2017). Economic Growth And Income Disparity Between Regencies/Cities In West Java Province. Eko-Regional Jurnal Pengembangan Ekonomi Wilayah, 12(2). Https://Doi.Org/10.20884/1.Erjpe.20 17.12.2.1139

Mulyana, N., Fauziyyah, H., Resnawaty, R., Barat, J., Padjadjaran, U., \& Tinggi, S. (2017). Pengembangan Ekonomi Lokal Jatinangor. Social Work Jurnal, 7, 1-129. Retrieved From

Https://Www.Researchgate.Net/Publ ication/319672031_Pengembangan_ Ekonomi_Lokal_Jatinangor_Melalui _Wisata_Edukasi

Nugroho, A. A. (2018). Pembangunan Ekonomi Berbasis Potensi Wilayah Dan Pemberdayaan Masyarakat: Analisis Pengembangan Ekonomi Kabupaten Ngawi. Jurnal 
Pembangunan Dan Kebijakan Publik, 8(2), 30-36.

Nuraini, E. (2017). Pengaruh pertumbuhan ekonomi dan tingkat pendidikan terhadap disparitas pendapatan di wilayah gerbangkertosusila. Jurnal ekonomi pendidikan dan kewirausahaan, $5(1), \quad 52$. Https://Doi.Org/10.26740/Jepk.V5n1. P52-67

Surabaya, B. P. S. K. (2018). Kota Surabaya Dalam Angka 2018.

$\square \square \square \square \square, 1(4), 53$.

Syariful. (2018). Ekonomi Kreatif Berbasis Kearifan Lokal Di Bangka Belitung. Jurnal Ekonomi Syariah, 1, 1-17.

Xue, J. (2012). Educational Disparity And Income Disparity. In Growth With Inequality: An International Comparison On Income Distribution (Pp. 255-276). Https://Doi.Org/10.1142/9789814401 708_0013 